Linguista: Jurnal Ilmiah Bahasa, Sastra, dan Pembelajarannya

Vol.3, No.2, Desember 2019, hal 120-132

ISSN (print): 2579-8944; ISSN (online): 2579-9037

Avaliable online at: http://e-journal.unipma.ac.id/index.php/linguista

\title{
Penerapan Model Pembelajaran Berbasis Pengalaman (Experiential Learning) dengan Menggunakan Media Gambar dalam Pembelajaran Menulis Karangan Deskripsi pada Siswa Kelas IV MI Riyadlatul Uqul
}

\author{
Pipit Puspitowati \\ MI RIYADLATUL UQUL, JI. Masjid RT 04 Kranggan, Kabupaten Madiun, Indonesia \\ e-mail: pipitpuspitowati78@gmail.com
}

\begin{abstract}
Abstrak
Penelitian ini bertujuan untuk mendeskripsikan (1) penerapan model belajar berbasis pengalaman (experiential learning) dengan menggunakan media gambar dalam pembelajaran menulis karangan deskripsi, (2) hasil belajar penerapan model belajar berbasis pengalaman (experiential learning) dengan menggunakan media gambar dalam pembelajaran menulis karangan deskripsi, (3) kelebihan dan kekurangan penerapan model belajar berbasis pengalaman (experiential learning) menggunakan media gambar dalam pembelajaran menulis karangan deskripsi. Penelitian ini menggunakan metode kualitatif deskriptif dengan subjek hasil karangan deskripsi siswa kelas IV MI Riyadlatul Uqul Kranggan Kecamatan Geger Kabupaten Madiun. Teknik pengumpulan data dalam penelitian ini adalah dengan obsevasi, wawancara, dan juga dokumentasi. Teknik yang digunakan untuk menganalisis data dalam penelitian ini adalah model interaktif dari Miles dan Huberman. Simpulan penelitian ini adalah (1) Penerapan model pembelajaran berbasis pengalaman (experiential learning) dengan menggunakan media gambar dalam pembelajaran menulis karangan deskripsi pada siswa kelas IV MI Riyadlatul Uqul Kranggan Kecamatan Geger Kabupaten Madiun berjalan sesuai yang direncanakan; (2) Penerapan model pembelajaran berbasis pengalaman (experiential learning) dengan menggunakan media gambar terbukti berhasil meningkatkan kemampuan siswa kelas IV MI Riyadlatul Uqul Kranggan Kecamatan Geger Kabupaten Madiun dalam pembelajaran menulis karangan deskripsi; (3) kelebihan penerapan model belajar berbasis pengalaman dengan menggunakan media gambar yaitu mampu menciptakan situasi belajar yang kondusif, mampu menumbuhkan semangat siswa dalam mengikuti setiap tahapan pembelajaran, dan juga mampu merangsang siswa agar lebih berpikir kreatif. Sedangkan, kelemahannya adalah membutuhkan perencanaan waktu dan pelaksanaan yang lama.
\end{abstract}

Kata kunci: Menulis Karangan Deskripsi; Experintal Learning; Media Gambar.

\section{Implementation of Experiential Learning with Using Picture in Writing Description for the Fourth Grade Students of MI Riyadlatul Uqul}

\begin{abstract}
This research aims to describe (1) the application of experiential learning models using picture media in learning to write description essays, (2) the learning outcomes of applying experiential learning models using experiential learning using picture media in learning to write description essays, (3) experience-based learning models and the advantages of applying experiential learning using picture media in learning to write essays of description. This study used a descriptive qualitative method with the subject of the essay description of the fourth grade students of MI Riyadlatul Uqul Kranggan in
\end{abstract}


Geger District, Madiun Regency. Data collection techniques in this research were observation, interview, and documentation. The technique used to analyze the data in this study was an interactive model from Miles and Huberman. The results of this study are that (1) The application of experiential learning model using picture media in writing essay description for the fourth grade students of MI Riyadlatul Uqul Kranggan Geger District Madiun Regency can be adjusted as needed; (2) The application of experiential learning models using picture media has proven to be successful in improving the ability of the fourth grade students of MI Riyadlatul Uqul Kranggan in Geger district, Madiun Regency in learning to write descriptive essays; (3) benefit-based learning models using image media that is able to make learning conducive learning, able to foster student enthusiasm in participating in each learning, and also able to encourage students to think more creatively. Meanwhile, the weakness is the need for long time planning and implementation.

Keywords: Writing Descriptive Esay; Experiental Learning; Picture Media.

\section{Pendahuluan}

Salah satu cara meningkatkan sumber daya manusia yang unggul dan berdaya saing adalah melalui pendidikan. Menurut Undang-Undang Dasar Republik Indonesia nomor 20 tahun 2003 tentang Sisdiknas, pendidikan didefinisikan sebagai usaha sadar dan terencana untuk mewujudkan suasana belajar dan proses pembelajaran yang mengembangkan potensi diri siswa untuk memliki kekuatan spiritual, keagamaan, pengendalian diri, kecerdasan, akhlak mulia, serta keterampilan diri. Dalam kegiatan belajar dan mengajar, Bahasa Indonesia merupakan salah satu mata pelajaran yang diajarkan di sekolah dasar. Pembelajaran Bahasa Indonesia diharapkan dapat membantu peserta didik mengenal dirinya, budayanya, dan budaya orang lain, mengemukakan gagasan dan perasaan, berpartisipasi dalam masyarakat yang menggunakan bahasa tersebut, dan menemukan serta menggunakan kemampuan analitis dan imaginatif yang ada didalam dirinya. Selain itu, pembelajaran Bahasa Indonesia diarahkan untuk meningkatkan kemampuan peserta didik untuk berkomunikasi dalam bahasa Indonesia dengan baik dan benar, baik secara lisan maupun tulisan, serta menumbuhkan apresiasi terhadap hasil karya kesastraan manusia Indonesia. Untuk itu, siswa secara umum diharuskan untuk menguasai empat komponen keterampilan berbahasa.

Empat komponen ketrampilan itu terdiri dari keterampilan menyimak (listening skills), keterampilan berbicara (speaking skills), keterampilan membaca (reading skills), dan keterampilan menulis (writing skills). Dari keempat keterampilan berbahasa tersebut, keterampilan menulis berada pada tataran tertinggi karena menulis merupakan kegiatan yang produktif atau menghasilkan.

Kata menulis atau mengarang merupakan dua kata yamg sudah sangat akrab di telinga kita. Salah satu keterampilan menulis yang perlu diperhatikan dan dikuasai ialah keterampilan menulis karangan. Mengarang pada hakikatnya ialah mengungkapkan atau menyampaikan gagasan dalam bentuk kalimat, paragraf, maupun karangan yang utuh menggunakan bahasa tulis (Suparno \& Yunus, 2007:31). Menulis itu sendiri bukanlah suatu yang baru bagi siswa. Artikel, esei, laporan, resensi, karya sastra, cerita rakyat, dan sebagainya adalah produk bahasa tulis yang akrab dengan kehidupan siswa.

Namun, yang menjadi masalah adalah rendahnya keterampilan menulis atau kemampuan mengarang siswa. Di kalangan siswa, terutama siswa sekolah dasar. 
Berdasarkan studi pendahuluan, kondisi awal yang terdapat di lapangan menunjukkan bahwa keterampilan menulis karangan siswa masih tergolong rendah. Rendahnya keterampilan menulis karangan siswa disebabkan oleh beberapa faktor yang mempengaruhi, salah satunya dikarenakan penerapan model pembelajaran yang kurang tepat dalam kegiatan belajar dan mengajar Bahasa Indonesia terutama keterampilan menulis.

Salah satu model yang dapat diterapkan dalam pembelajaran bahasa Indonesia tentang menulis karangan adalah model pembelajaran berbasis pengalaman (experiential learning) dengan menggunakan media gambar. Model pembelajaran berbasis pengalaman (experiential learning) ialah model pembelajaran yang didasarkan pada pemikiran bahwa pengalaman hidup siswa memainkan peran sentral dalam pembelajaran dan pemahaman pengetahuan baru mereka (Bartle, 2015:3). Model pembelajaran berbasis pengalaman (experiential learning) menyediakan kesempatan bagi siswa untuk mengembangkan dan membangun pengetahuan melalui pengalamannya. Artinya, siswa akan terlibat secara langsung selama proses pembelajaran dan akan memperoleh pengalaman yang bermakna. Melalui pengalamanpengalaman tersebut, siswa diharapkan mampu menghasilkan tulisan atau karangan yang sesuai dengan pengalamannya sendiri, bukan berasal dari fantasi atau anganangan saja.

Selain penerapan model pembelajaran berbasis pengalaman (experiential learning), media dalam pembelajaran menulis karangan deskripsi juga harus diperhatikan. Pemilihan media yang tepat dalam pembelajaran diharapkan mampu meningkatkan kemampuan menulis terutama menulis paragraf deskripsi. Hal ini sesuai dengan pendapat Rahardjo (2006:7) yang menyatakan media adalah segala sesuatu yang dapat digunakan untuk menyalurkan pesan dari pengirim ke penerima sehingga dapat merangsang pikiran, perasaan, perhatian dan minat serta perhatian siswa sedemikian rupa sehingga proses belajar terjadi.

Salah satu media yang dipilih untuk menunjang prestasi belajar menulis karangan deskripsi adalah dengan menggunakan media gambar. Dengan menggunakan media gambar, diharapkan siswa mampu menyusun karangan deskripsi berdasarkan pengamatan terhadap gambar, dengan cara mendeskripsikan gambar tersebut secara logis dan runtut sesuai gambar. Kelebihannya, media gambar seri umumnya harganya murah, mudah didapat, mudah dipergunakan, dapat memperjelas suatu masalah, lebih realistis, dapat mengatasi keterbatasan pengamatan, dan dapat mengatasi keterbatasan ruang dan waktu. Selain itu, penggunaan media gambar merupakan salah satu cara merangsang siswa untuk menghadirkan kembali ingatan siswa berdasarkan pengalamannya.

Berangkat dari latar belakang di atas, peneliti tertarik untuk melakukan penelitian pengamatan mengenai Penerapan Model Pembelajaran Berbasis Pengalaman (Experiential Learning) dengan Menggunakan Media Gambar dalam Pembelajaran Menulis Karangan Deskripsi Siswa Kelas IV MI Riyadlatul Uqul Kranggan Kecamatan Geger Kabupaten Madiun. Alasan peneliti memilih penelitian penerapan model pembelajaran berbasis pengalaman (experiential learning) dengan menggunakan media gambar sebagai salah satu cara merangsang kemampuan menulis karangan deskripsi sebab sejauh ini penelusuran kepustakaan mengenai kajian penerapan model pembelajaran berbasis pengalaman (experiential learning) dengan menggunakan media 
gambar belum banyak ditemukan. Dengan demikian, dalam penelitian pengamatan ini akan dijelaskan bagaimana penerapan model pembelajaran berbasis pengalaman (experiential learning) dan penggunaan media gambar sebagai salah satu cara merangsang kemampuan menulis karangan deskripsi siswa kelas IV MI Riyadlatul Uqul Kranggan Kecamatan Geger Kabupaten Madiun.

\section{Metode Penelitian}

Jenis penelitian yang akan digunakan peneliti adalah deskriptif kualitatif. Datadata pada penelitian ini tidak berupa angka-angka, tetapi berupa kata-kata. Hal ini sesuai dengan pendapat Kriyantono (2006:58) yang menyatakan bahwa penelitian kualitatif adalah penelitian yang menjelaskan suatu fenomena dengan sedalam-dalamnya, melalui pengumpulan data yang lebih mengutamakan kualitas bukan kuantitas data. Rahkmat (2008:24) menegaskan bahwa penelitian deskriptif hanya akan memaparkan situasi atau peristiwa sehingga peneliti tidak perlu mencari atau menjelaskan hubungan, serta tidak menguji hipotesis.

Pendekatan yang digunakan dalam penelitian kualitatif deskriptif ini adalah pendekatan pengamatan kelas (class observation research). Dijelaskan oleh Firman (2007:27) mengungkapkan bahwa penelitian kelas adalah suatu upaya untuk menjelaskan berbagai aspek dari hubungan antarketergantungan materi subjek, pembelajar, dan pengajar sehubungan dengan isu totalitas dan logika internal dari tugas mengonstruksi pengetahuan dari PBM. Fokus penelitian ini adalah pelaksanaan pembelajaran menulis karangan deskripsi dengan menggunakan model pembelajaran berbasis pengalaman (experiential learning) dengan menggunakan media gambar pada siswa kelas IV MI Riyadlatul Uqul Kranggan Kecamatan Geger Kabupaten Madiun tahun ajaran 2018/2019.

Pendekatan ini dipilih karena terdapat tahapan mendeskripsikan, serta menjelaskan penerapan model pembelajaran berbasis pengalaman (experiential learning) dengan menggunakan media gambar dalam pembelajaran menulis karangan deskripsi. Oleh karena itu, hal tersebut harus digali secara mendalam tanpa reduksi ataupun isolasi terhadap variabel-variabel tertentu sehingga diperoleh data-data yang lengkap dan mampu menjelaskan secara komprehensif. Data dalam penelitian ini berupa sejumlah informasi yang berkaitan dengan penerapan model pembelajaran berbasis pengalaman (experiential learning) dengan menggunakan media gambar. Data-data tersebut diperoleh dari berbagai sumber data yang tersedia di lokasi penelitian.

Sumber data digunakan untuk mendapatkan data dalam sebuah penelitian. Sutopo (2002: 49-51) menyatakan bahwa data-data penelitian kualitatif dapat digali dari informan (nara sumber), peristiwa atau aktivitas, tempat atau lokasi, dan dokumen atau arsip. Sesuai dengan pendapat tersebut dan berdasarkan jenis data yang dibutuhkan, jenis sumber data yang dipergunakan dalam penelitian ini adalah (1) informan atau nara sumber, (2) peristiwa atau aktivitas, (3) dokumen atau arsip. Teknik pengumpulan data ntuk mendapatkan suatu data yang valid, peneliti perlu mempunyai teknik pengumpulan data yang tepat. Pengumpulan data penelitian guna memberikan data yang diperlukan untuk menjawab permasalahan dengan menggunakan peninjauan langsung pada instansi yang dijadikan objek penelitian. Sesuai dengan karakteristik dan jenis data yang 
diperlukan, teknik pengumpulan data yang dipergunakan dalam penelitian ini adalah observasi, wawancara dan dokumentasi.

Penelitian mengenai penerapan model pembelajaran berbasis pengalaman dan penggunaan media gambar dalam pembelajaran menulis karangan deskripsi ini dilaksanakan kurang lebih enam bulan, dimulai pada bulan September 2017 hingga bulan Agustus 2018. Untuk dapat menyelesaikan penelitian ini, peneliti menguraikan beberapa tahapan penelitian adalah tahap persiapan, tahap pelaksanaan dan tahap penyelesaian. Dalam penelitian ini, peneliti menggunakan teknik keabsahan data triangulasi. Triangulasi adalah teknik pemeriksaan keabsahan data yang memanfaatkan sesuatu yang lain di luar data untuk keperluan pengecekan atau sebagai pembanding terhadap data itu. Menurut Moleong (2007:330) triangulasi, yaitu suatu teknik pemeriksaan keabsahan data yang memanfaatkan sesuatu yang lain. Triangulasi dalam pengujian kredibilitas ini diartikan sebagai pengecekan data dari berbagai sumber dengan berbagai cara. Triangulasi yang digunakan dalam penelitian ini adalah trianggulasi sumber dan trianggulasi teknik.

Untuk menghasilkan sebuah penelitian yang baik, diperlukan teknik analisis yang tepat. Teknik yang digunakan untuk menganalisis data dalam penelitian ini adalah teknik deskriptif kualitatif, yakni analisis dengan mendeskripsikan segala sesuatu hal yang ditemukan dalam penelitian berdasarkan fakta atau fenomena secara empiris (Sudaryanto, 2008:62-63). Penelitian ini berusaha mengkaji dan memberikan penilaian terhadap hasil karya siswa dalam menulis karangan deskripsi. Penelitian ini akan menjelaskan penerapan model pembelajaran berbasis pengalaman (experiential learning) dan penggunaan media gambar. Adapun analisis data model interaktif dalam penelitian ini sebagai berikut. (1) Melakukan penilaian terhadap hasil karangan deskripsi siswa, (2) Melakukan pereduksian data karangan deskripsi siswa, (3) Memasukkan data ke komputer agar data yang terkumpul dapat dicek kembali, (4) Melakukan penarikan simpulan dan verifikasi data.

\section{Hasil dan Pembahasan}

Pada bagian ini, peneliti melakukan kajian yang mendalam tentang penerapan penerapan model pembelajaran berbasis pengalaman (experiential learning) dengan menggunakan media gambar dalam pembelajaran menulis karangan deskripsi kelas IV MI Riyadlatul Uqul Kranggan Kecamatan Geger Kabupaten Madiun. Tujuannya adalah untuk mendapatkan deskripsi penerapan penerapan model pembelajaran berbasis pengalaman (experiential learning) dan penggunaan media gambar dalam pembelajaran menulis karangan deskripsi. Penelitian pengamatan penerapan model pembelajaran berbasis pengalaman (experiential learning) dengan menggunakan media gambar dalam pembelajaran menulis karangan deskripsi kelas IV MI Riyadlatul Uqul Kranggan Kecamatan Geger Kabupaten Madiun. Pengumpulan data dilakukan melalui wawancara dengan informan, observasi terhadap kegiatan pembelajaran di kelas, serta studi dokumen terhadap silabus, Rencana Pelaksanaan Pembelajaran (RPP), dan dokumendokumen lain yang berkaitan dengan pembelajaran menulis karangan deskripsi.

Kegiatan pembelajaran dimulai dengan membuka kegiatan pembelajaran. Pada pertemuan setiap pertemuan, guru selalu memberi salam dan kata-kata motivasi kepada siswa agar siswa selalu optimis, semangat dan antusias dalam setiap kegiatan pembelajaran. Setelah kegiatan pembuka selesai dilaksanakan, kegiatan dilanjutkan 
dengan berdoa sebelum dimulai pelajaran. Guru mempresensi kehadiran peserta didik serta mengamati kesiapan peserta didik dalam proses pembelajaran. Sebelum memulai inti pelajaran, guru menyampaikan tujuan pembelajaran dan memberitahukan bahwa proses pembelajaran akan menerapkan model pembelajaran berbasis pengalaman (experiential learning) dengan menggunakan media gambar. Guru menjelaskan langkah-langkah model pembelajaran yang diterapkan karena hal ini merupakan sesuatu yang baru bagi siswa. Sebelum memulai pelajaran, guru memberitahu bahwa nilai peserta didik didapat dari tugas kelompok dan tugas individu. Saat pemebelajaran sedang berlangsung guru mengarahkan siswa untuk melakukan observasi lapangan. Guru juga membimbing siswa dalam menganalisis data hasil observasi lapangan. Guru membimbing siswa dalam menulis karangan deskripsi berdasarkan gambar. Diakhir pembelajaran guru merefleksi hasil tulisan siswa.

Hasil penilaian pengamatan terhadap guru menunjukkan hasil yang baik. Dari tabel di atas, dapat dilihat bahwa guru mampu menerapkan model pembelajaran berbasis pengalaman (experiential learning) dengan menggunakan media gambar dalam pembelajaran menulis karangan deskripsi pada siswa kelas IV MI Riyadlatul Uqul Kranggan Kecamatan Geger Kabupaten Madiun.

Selanjutnya, guru mengajak siswa untuk membentuk sebuah kelompok. Setiap kelompok beranggotakan lima orang siswa. Pada saat membentuk kelompok ini, kondisi kelas kurang kondusif sehingga guru mengambil keputusan bahwa pembentukan kelompok berdasarkan nomor urutan tempat duduk. Siswa diminta mengurutkan nomor satu sampai lima. Siswa yang meneriakkan nomor satu akan bergabung dengan siswa lain yang meneriakkan nomor satu hingga semua siswa mendapat anggota kelompok dengan penuh kegembiraan.

Kegiatan selanjutnya adalah guru mengajak siswa mengunjungi sebuah pabrik yang memproduksi soun yang letaknya tak jauh dari sekolah. Siswa yang terbagi ke dalam tiga kelompok mengobseravasi tiga tempat yang berbedda. Kelompok pertama mengunjungi ruang pembungkusan soun, kelompok kedua mengunjungi ruang pengolahan soun, dan yang terakhir kelompok ketiga mengunjungi ruang pengeringan soun. Guru meminta siswa menuliskan benda apa saja yang mereka dapatkan dari hasil obsevasi. Setelah kegiatan ini selesai, guru meminta siswa berkumpul kembali dan segera menuju sekolah.

Setelah guru memastikan bahwa semua siswa telah duduk kembali di bangku masing-masing, guru meminta siswa untuk bergabung kembali bersama kelompoknya guna mendiskusikan temuan-temuan observasi pada saat berkunjung ke pabrik produksi soun. Untuk membantu ingatan siswa mengenai hasil observasi di pabrik produksi soun, guru membagikan foto-foto pabrik soun. Kemudian, guru meminta siswa mendiskusikan kata-kata yang telah ditulis berdasarkan hasil observasi di pabrik soun kemudian menyusunnya sebagai kalimat utama berdasarkan gambar foto yang diberikan oleh guru.

Guru juga meminta siswa mengembangkan paragraf sesuai dengan kalimat utama yang telah dibuat. Pada tahap ini, siswa terlihat aktif menuangkan ide-ide mereka dan membaginya ke kelompok masing-masing. Setelah diskusi selesai, siswa diminta untuk mempresentasikan hasil diskusi dan menggambarkan pengalamannnya berkunjung di pabrik soun. Kelompok yang lain memerhatikan dan menanggapi hasil diskusi kelompok penyaji. Pada tahap ini, siswa tampak aktif melontarkan pertanyaan- 
pertanyaan. Rasa keingintahuan siswa yang besar ini timbul karena guru mampu memancing rasa penasaran siswa.

Setelah semua kelompok mempresentasikan hasil diskusi kunjungan ke pabrik soun, guru dan siswa bersama-sama menyimpulkan hasil pembelajaran. Guru menguatkan temuan-temuan siswa dengan memberikan penjelasan bahwa apa yang dilakukan siswa pada pertemuan kali ini sesuai dengan tujuan pembelajaran. Siswa sangat senang dan antusias ketika guru memberi penguatan materi dan motivasimotivasi untuk terus belajar. Siswa juga menyampaikan ingin pembelajaran berbasis pengalaman dengan menggunakan media gambar diterapkan juga pada materi-materi yang lain.

Selama pembelajaran menulis karangan deskripsi dengan menerapkan model pembelajaran berbasis pengalaman (experiential learning) dengan menggunakan media gambar berlangsung, pengamatan terhadap siswa juga dilaksanakan agar mendapatkan data yang objektif. Pengamatan (observasi) dilakukan sendiri oleh peneliti. Peneliti mengisi lembar-lembar pengamatan yang telah disiapkan yang terdiri atas pengamatan terhadap siswa dan guru.

Hasil wawancara dengan beberapa siswa menunjukkan bahwa siswa sangat antusias pada saat pembelajaran menulis deskripsi. Sesuai hasil wawancara pada lampiran. Beberapa siswa mengatakan bahwa pembelajaran ini sangat menyenangkan. Mereka dengan mudah menyelesaikan tugas dan menulis karangan deskripsi yang diberikan oleh guru. Mereka juga mengatakan ingin guru mengulangi pembelajaran seperti ini saat mengajarkan materi lainnya.

Berdasarkan pengamatan peneliti dalam setiap tahapan pembelajaran yang meliputi pada pertemuan awal, masih banyak siswa yang kurang memperhatikan penjelasan dari guru. Namun, hal ini tidak berlangsung lama. Selain itu, masih juga ditemukan siswa yang bercanda dengan temannya atau bermain sendiri dan tidak fokus atas tugas yang diberikan saat kegiatan kunjungan ke pabrik soun berlangsung. Namun, ketika semua siswa telah kembali ke kelas dan bergabung dengan kelompoknya untuk berdiskusi, siswa dalam keadaan yang baik dan telah memiliki bekal mengenai karangan deskripsi dan model pembelajaran berbasis pengalaman (experiential learning) sehingga kegiatan diskusi kelompok dan juga presentasi hasil diskusi kelompok berjalan dengan baik. Hal ini ditandai dengan banyaknya siswa yang bertanya dan berani mengapresiasi hasil diskusi kelompok lain. Siswa telah menguasai dan memahami betul materi karangan deskripsi. Sehingga, ketika guru meminta siswa membuat karangan deskripsi secara individu, siswa sangat antusias menuangkannya ke dalam sebuah karangan.

Model pembelajaran berbasis pengalaman (experiential learning) dan penggunaan media gambar pada pembelajaran menulis karangan deskripsi sangat membantu siswa dalam memahami materi pelajaran. Hal ini dikarenakan model pembelajaran berbasis pengalaman (experiential learning) dengan menggunakan media gambar dekat dengan kehidupan sehari-hari siswa. Pengalaman siswa inilah yang menjadi dasar utama model pembelajaran, sedangkan penggunaan media gambar pada pembelajaran menulis karangan deskripsi untuk menguatkan ingatan siswa untuk menggambarkan kondisi atau peristiwa pada saat siswa mengalami pengalaman itu.

Model pembelajaran berbasis pengalaman (experiential learning) dengan menggunakan media gambar bukan hanya bisa digunakan untuk penilaian tugas 
kelompok saja, melainkan juga bisa digunakan untuk mendapatkan penilaian tugas mandiri atau individu. Selain itu, model pembelajaran berbasis pengalaman (experiential learning) dengan menggunakan media gambar juga sangat sesuai digunakan pada materi pelajaran selain menulis karangan deskripsi.

Penerapan model pembelajaran berbasis pengalaman (experiential learning) dengan menggunakan media gambar dalam pembelajaran menulis karangan deskripsi memberi dampak positif pada kegiatan belajar siswa kelas IV MI Riyadlatul Uqul Kranggan Kecamatan Geger Kabupaten Madiun. Pemerolehan nilai siswa lebih baik bila dibandingkan dengan nilai siswa sebelum diterapkannya model pembelajaran berbasis pengalaman (experiential learning) dengan menggunakan media gambar. Dalam penerapan model pembelajaran berbasis pengalaman (experiential learning) dengan menggunakan media gambar, penilaian diambil secara individu. Hal ini dilakukan untuk mengukur sejauh mana siswa memahami materi karangan deskripsi. Nilai tertinggi 89; nilai terendah 72 ; dan rata-rata nilai adalah 81.80 .

. Nilai KKM pada pembelajaran menulis 75 , hal ini berarti hanya dua anak yang mendapat nilai di bawah KKM. Berikut pembahasan dari tugas individu tersebut. Salah satu siswa yang mendapat nilai tinggi adalah SV. SV begitu gamblang mendeskripsikan situasi ruang pengeringan sesuai dengan pengalaman berkunjung ke pabrik dan media gambar foto yang telah disiapkan oleh guru. Susunan antarkalimat juga runtut dan sistematis. Selain itu, tulisan tangan SV juga tergolong rapi. Isi gagasan yang dikemukakan SV, sesuai dengan tema ditulis secara padat dan lengkap, dalam tapenilaian isi gagasan SV memperoleh skor 14. Dari hasil pendeskripsian SV juga menggambaran lingkungan atau tempat yang diamati sangat teliti dan melukiskannya secara jelas serta mengembangkan ide-ide gagasan sangat mendalam, sehingga skor yang diperoleh 14. Pada organisasi isi SV mengungkapkan gagasan dengan jelas tertata dengan baik, urutan logis dan kohesif, sehingga pada tahapan organisasi isi SV mendapat skor 20. Struktur kata bahasa yang digunakan SV seerhana tetapi efektif, terjadi sejumlah kesalahan tetapi makna tidak kabur. Dalam struktur tata bahasa SV memperoleh skor 16. Pilihan struktur dan diksi SV memperoleh skor 14 karena SV memanfaatkan potensi kata canggih, pilihan kata dan ungkapan tepat, menguasai pembentukan kata. SV menguasai aturan penulisan, hanya terjadi beberapa keslahan saja. Sehingga SV memdapatkan skor 11. Selain SV masih ada 6 teman SV yang mendapat nilai tinggi.

Hasil penilaian tugas individu yang berada pada tingkatan nilai tengah berkisar di antara nilai 76 sampai 82 . Siswa yang mendapat rentang nilai 76-82 sebanyak enam siswa. Pembahasan data hasil tugas individu siswa yang mendapat nilai tengah sebagai berikut. Salah satu siswa yang memeroleh nilai rentang tengah adalah siswa yang bernama YD. Isi gagasan yang dikemukakan YD, sesuai dengan tema ditulis secara padat dan lengkap, dalam penilaian isi gagasan YD memperoleh skor 14. Dari hasil pendeskripsian YD juga menggambaran lingkungan atau tempat yang diamati sangat teliti dan melukiskannya secara jelas serta mengembangkan ide-ide gagasan sangat mendalam, sehingga skor yang diperoleh 14. Pada organisasi isi YD kurang terorganisir, urutannya tidak logis dan kurang lengkap, sehingga YD memperoleh skor 18. Dalam struktur tata bahasa YD memperoleh skor 13 karena terjadi kesalahan serius dalam tata bahasa, makna membigungkan dan kabur. Pilihan struktur dan diksi YD memperoleh skor 14 karena YD memanfaatkan potensi kata canggih, pilihan kata dan ungkapan 
tepat, menguasai pembentukan kata. YD memanfaatkan potensi kata terbatas sering terjadi kesalahan penggunaan kosa kata dan dapat merusak makna, sehingga YD memdapatkan skor 9. YD tidak bisa maksimal.

Nilai terendah berada di angka 72. Pemerolehan nilai di bawah KKM ini disebabkan oleh belum pahamnya siswa tersebut terhadap materi karangan deskripsi. Hal ini akan dibahas sebagai berikut. Siswa yang mendapat nilai kurang adalah siswa bernama RF. Isi gagasan yang dikemukakan RF sesuai dengan tema tetapi terbatas da kurang tuntas. RF memperoleh skor 12 pada isi gagasan. Penggambaran terhadap lingkungan atau tempat yang diamati kurang teliti dan melukiskannya kurang jelas serta pengembangan ide-ide gagasan cukup mendalam sehingga RF memperoleh skor 12 . Pada organisasi isi, RF mengemukakan gagasanya tidak terorganisir, urutan tidak logis dan tidak lengkap, sehingga RF memperoleh skor 15. RF memperoleh skor 13 dalam struktur tata bahasa karena terjdi kesalahan serius dalam tata bahasa, makna membingungkan dan kabur. Pilihan struktur dan diksi, RF memanfaatkan kata agak canggih, pilihan kata kadang-kadang kurang tepat namun tidak menggnggu, sehingga skor yang diperolah 13. Pada ejaan dan tanda baca RF, kadang-kadang terjadi kesalahan ejaan tetapi tidak mengaburkan makna. RF memperoleh skor 8 dalam penilaian ejaan dan tanda baca.

Model belajar berbasis pengalaman (experiential learning) dengan menggunakan media gambar dalam pembelajaran menulis karangan deskripsi yang diterapkan pada siswa kelas IV MI Riyadlatul Uqul Kranggan Kecamatan Geger Kabupaten Madiun memiliki beberapa kelebihan.

Dalam penerapan model belajar berbasis pengalaman (experiential learning) dengan menggunakan media gambar mampu membuat situasi belajar yang kondusif. Hal ini disebabkan model pembelajaran ini jarang diterapkan oleh guru. Sehingga, ketika guru menerapkan model belajar seperti ini, siswa merasakan suasana yang berbeda. Situasi belajar yang kondusif berdampak positif terhadap semangat siswa dalam mengikuti pembelajaran. Siswa menjadi semakin tertantang untuk mendapatkan pengalaman belajar yang baru tanpa harus mengesampingkan materi pembelajaran.

Peningkatan motivasi dan semangat belajar siswa sangat memengaruhi meningkatnya pula proses berpikir kreatif. Proses berpikir kreatif ini sangat diperlukan dalam kegiatan belajar agar siswa semakin aktif dan memahami benar materi-materi pembelajaran. Dalam pembelajaran ini perpaduan antara media pembelajaran berbasis pengalaman (experiential learning) dengan menggunakan media gambar membuat siswa berpikir kreatif. Mereka dapat menyelesaikan tugas menulis karangan deskripsi dengan hasil yang memuaskan.

Pembelajaran yang menarik membuat siswa bersemangat. Siswa mendapat kosa kata baru dari pengalaman yang mereka alami. Sehingga diharapkan mampu membuat paragraf deskripsi dengan baik dan runtut.

Penerapan model pembelajaran berbasis pengalaman (experiential learning) dengan menggunakan media gambar dalam pembelajaran menulis karangan deskripsi yang diterapkan di kelas IV MI Riyadlatul Uqul Kranggan Kecamatan Geger Kabupaten Madiun juga menemui kekurangan.

Penerapan model pembelajaran ini, harus mempersiapkan secara matang, pelaksanan model pembelajaran berbasis pengalaman (experiential learning) dengan menggunakan media, gambar dalam pembelajaran menulis karangan deskripsi juga 
membutuhkan waktu yang cukup lama. Sehingga guru dituntut memiliki perencanaan waktu yang baik agar setiap tahapan pelaksanaan kegiatan pembelajaran tidak ada yang terlewat. Hal tersebut dapat diamati dalam Rencana Pelaksanaan Pembelajaran bahwa kegiatan tersebut memerlukan waktu 175 menit yang terbagi dalam 35 menit kegiatan awal, 115 menit kegiatan inti dan 20 menit pada kegiatan akhir.

Kondisi siswa yang heterogen menyebabkan masing-masing siswa memiliki pengalaman yang berbeda-beda. Meskipun guru telah menyiapkan materi yang dekat dengan keseharian siswa, tidak menutup kemungkinan beberapa siswa ada yang belum pernah merasakan pengalaman tersebut. Hal ini membuat guru harus merangsang, menuntun, dan juga membimbing siswa tersebut agar memiliki pandangan seperti yang diharapkan.

Hasil penilaian pengamatan siswa menunjukkan hasil yang baik. Siswa mendengarkan penjelasan guru tentang karangan deskripsi dengan baik meskipun di awal pemebelajaran kondisi siswa kurang terkontrol. Siswa melakukan observasi lapangan siswa dengan tertib. Bersama kelompoknya, mereka mengunjungi tempat yang sudah ditetapkan. Setelah kembali ke kelas siswa menganalisis data hasil observasi lapangan. Siswa menentukan judul dan tema berdasarkan analisis data observasi lapangan. Dalam kegiatan kelompok ini siswa sangat bersemangat dalam menyelesaikan tugas menulis karangan deskripsi. Siswa menulis kalimat utama berdasarkan gambar. Siswa menulis karangan deskripsi berdasarkan gambar ysng sudah disiapkan oleh guru. Siswa juga mempresentasikan hasil karangan deskripsi di depan kelas bersama kelompoknya. Siswa aktif dalam kegiatan pembelajaran saat pembelajaran berlangsung.

Temuan penelitian ini sesuai dengan penelitian Medianna (2016) yang menyatakan bahwa kemampuan siswa dalam menulis karangan narasi baik dari segi aktivitas maupun hasil dengan menggunakan model experiential learning meningkat.

Selama kegiatan pembelajaran berlangsung, hasil pengamatan menunjukkan bahwa siswa antusias mengikuti pembelajaran menulis karangan deskripsi. Pada pertemuan awal, masih banyak siswa yang kurang memperhatikan penjelasan dari guru. Namun, hal ini tidak berlangsung lama. Selain itu, masih juga ditemukan siswa yang bercanda dengan temannya atau bermain sendiri dan tidak fokus atas tugas yang diberikan saat kegiatan kunjungan ke pabrik soun berlangsung. Namun, ketika semua siswa telah kembali ke kelas dan bergabung dengan kelompoknya untuk berdiskusi, siswa dalam keadaan yang baik dan telah memiliki bekal mengenai karangan deskripsi dan model pembelajaran berbasis pengalaman (experiential learning) sehingga kegiatan diskusi kelompok dan juga presentasi hasil diskusi kelompok berjalan dengan baik. Hal ini ditandai dengan banyaknya siswa yang bertanya dan berani mengapresiasi hasil diskusi kelompok lain. Siswa telah menguasai dan memahami betul materi karangan deskripsi. Sehingga, ketika guru meminta siswa membuat karangan deskripsi secara individu, siswa sangat antusias menuangkannya ke dalam sebuah karangan.

Hal ini sesuai dengan penelitian yang dilakukan oleh Mahmud (2015) yang menunjukkan bahwa penerapan model pembelajaran berbasis pengalaman (experiential learning) memberikan pengalaman belajar siswa lebih banyak. Hal ini disebabkan siswa dilatih untuk fokus dalam pemecahan materi. Selain itu, siswa dituntut untuk menjawab permasalahan dengan tepat dan mengungkapkan informasi yang mereka miliki sehingga terjadi pertukaran ilmu yang lebih dapat dicerna oleh siswa lainnya. 
Hal ini diperkuat dengan temuan Cahyani (2013:165) yang menyatakan bahwa manfaat pembelajaran experiential learning adalah meningkatkan semangat dan gairah pembelajar, membantu terciptanya suasana belajar yang kondusif, memunculkan kegembiraan dalam proses belajar, mendorong dan mengembangkan proses berfikir kreatif, menolong pembelajar untuk dapat melihat dalam perspektif yang berbeda, memunculkan kesadaran akan kebutuhan untuk berubah, memperkuat kesadaran diri.

Hasil penelitian ini senada dengan hasil penelitian Kuswandari (2017) juga menunjukkan bahwa penerapan model Experiential Learning dapat membuat siswa lebih memahami materi yang disampaikan guru dan membuat siswa berpikir kreatif untuk menuangkan hasil pengalamannya ke dalam sebuah karangan, sehingga nilai tes keterampilan menulis karangan dapat mencapai KKM.

\section{Kesimpulan}

Berdasarkan hasil penelitian dan pembahasan yang telah dilakukan, dapat disimpulkan sebagai berikut (1)Penerapan model pembelajaran berbasis pengalaman (experiential learning) dengan menggunakan media gambar dalam pembelajaran menulis karangan deskripsi pada siswa kelas IV MI Riyadlatul Uqul Kranggan Kecamatan Geger Kabupaten Madiun berjalan sesuai yang direncanakan. Pembelajaran menulis paragraf deskripsi dengan menerapkan model pembelajaran berbasis pengalaman (experiential learning) dan media gambar yang dilakukan pengajar mengikuti langkah-langkah pembelajaran yang sudah dirancang, (2) Penerapan model pembelajaran berbasis pengalaman (experiential learning) dengan menggunakan media gambar terbukti berhasil meningkatkan kemampuan siswa kelas IV MI Riyadlatul Uqul Kranggan Kecamatan Geger Kabupaten Madiun dalam pembelajaran menulis karangan deskripsi. Hal ini terbukti dengan perolehan nilai rata-rata setelah penerapan model pembelajaran berbasis pengalaman (experiential learning) dengan menggunakan media gambar berada pada nilai 81,80 , (3) Penerapan model pembelajaran berbasis pengalaman (experiential learning) dan penggunaan media gambar dalam pembelajaran menulis karangan deskripsi pada siswa kelas IV MI Riyadlatul Uqul Kranggan Kecamatan Geger Kabupaten Madiun memiliki beberapa kelebihan yaitu mampu menciptakan situasi belajar yang kondusif, mampu menumbuhkan semangat siswa dalam mengikuti setiap tahapan pembelajaran, dan juga mampu merangsang siswa agar lebih berpikir kreatif. Namun, penerapan model pembelajaran berbasis pengalaman (experiential learning) dengan menggunakan media gambar dalam pembelajaran menulis karangan deskripsi pada siswa kelas IV MI Riyadlatul Uqul Kranggan Kecamatan Geger Kabupaten Madiun juga menemui kendala di antaranya adalah membutuhkan perencanaan waktu dan pelaksanaan yang lama.

Setelah penelitian dilakukan, peneliti memiliki beberapa masukan terhadap pihak-pihak terkait. Bagi pendidik hasil penelitian ini dapat digunakan sebagai rujukan untuk menerapkan model pembelajaran berbasis pengalaman (expreiential learning) dengan menggunakan media gambar. Selain itu, penelitian ini juga dapat digunakan sebagai bahan rujukan untuk menciptakan pembelajaran yang menyenangkan sehingga kemampuan siswa dalam menulis karangan dapat ditingkatkan. Bagi peneliti selanjutnya hasil penelitian ini dapat digunakan untuk melakukan penelitian lebih lanjut yang berkaitan dengan model pembelajaran berbasis pengalaman (expreiential learning) 
dengan menggunakan media gambar dan juga penelitian mengenai pembelajaran menulis karangan.

\section{Daftar Pustaka}

Abidin, Y. (2012). Pembelajaran Bahasa Berbasis Pendidikan Karakter. Bandung: Refika Aditama.

Ahmadi, I.R dkk., (20110. Strategi Pembelajaran Sekolah Terpadu Pengaruhnya Terhadap Konsep Pembelajaran Sekolah Swasta dan Negeri. Jakarta: PT Prestasi Pustakaraya.

Akhadiah, S., dkk. (2007). Pembinaan Kemampuan Menulis Bahasa Indonesia. Jakarta: Erlangga.

Alfin, M. (2008). Metode Penelitian. Malang: Biro Penelitian LKP2M.

Arsyad, A.(2012). Media Pembelajaran. Jakarta: Raja Grafindo Persada

Cahyani, I. (2013). Pembelajaran Menulis Berbasis Karakter dengan Pendekatan Experiential Learning. Bandung: Program Studi Pendidikan Dasar SPS UPI.

Dalman. (2014). Keterampilan Menulis. Jakarta: Raja Grafindo Persada

DePorter, B. \& Hernacki, M. (2005). Quantum Learning: Membiasakan Belajar Nyaman dan Menyenangkan. Bandung: Kaifa.

Hairrudin, dkk. (2008). Pembelajaran Bahasa Indonesia. Jakarta: Direktorat Jenderal Pendidikan Tinggi Departemen Pendidikan Nasional.

Hamalik, O. (2009). Kurikulum dan Pembelajaran. Jakarta: Bumi Aksara

Jauharoti, A., dkk. (2008). Bahasa Indonesia 1. Surabaya: Lapis PGMI.

Keraf, Gorys. (2007). Komposisi. Jakarta: Ikrar Mandiri Abadi.

Kriyantono, R.(2006). Teknik Praktis Riset Komunikasi. Jakarta: Kencana

Kosasih. (2003). Kompetensi Ketatabahasaan dan Kesusastraan Cermat Berbahasa Indonesia. Bandung: Yrama Widya.

Kuswandari, D. (2017). Penerapan Model Experiential Learning Untuk meningkatkan Keterampilan Menulis pada siswa Kelas IV SD Negeri 4 Kawuyuhan. Kalam Cendekia FKIP UNS.

Mahmud, M. (2015). Pengaruh Metode Pembelajaran Berbasis Pengalaman (Experiential Learning) melalui Media Gambar terhadap Kemampuan Menulis Paragraf. Jurnal Seminar Nasional dan Temu Ilmiah Jaringan Peneliti. Banyuwangi: IAI Darussalam Blokagung.

Majid, A. (2014). Pendidikan Agama Islam Berbasis Kompetensi. Bandung: Remaja Rosdakarya.

Maulana, F. (2015). Implementasi Model Experiential Learning dalam Pembelajaran IPA Materi Energi dan Perubahan Siswa Kelas IV MI Miftahus Shibyan Mijen Semarang. Nadwa: Jurnal Pendidikan Islam. Semarang: UIN Semarang Press.

Mayer, R. E. (2009). Multimedia Learning Prinsip-Prinsip dan Aplikasi. (Terjemahan Teguh Wahyu Utomo). (C. U. Press, Ed.). New York.

Mediana, J. (2016). Penggunaan Model Experiential Learning Untuk Meningkatkan Kemampuan Menulis Karangan Narasi pada siswa Kelas III. Antologi Universitas Pendidikan Indonesia. 
Miles, M.B. dan Huberman, A.M. (1984). Qualitative Data Analysis A Source Book of New Methods. California: SAGE Publication.

Moleong, L. (2009). Metodologi Penelitian Kualitatif. Bandung: Remaja Rosdakarya

Moon, A. J. (2004). A Handbook of Reflective and Experiential Learning: Theory and Practice. London: Routledgefalmer.

Nurgiyantoro, B. (2011). Penilaian dalam pengajaran Bahasa dan Sastra Indonesia. Yogyakarta: BPFE.

Rahayu, M. (2007). Bahasa Indonesia di Perguruan Tinggi: Mata Kuliah Pengembangan Kepribadian. Bandung: Grasindo.

Rakhmat, J. (2008). Metode Penelitian Komunikasi. Bandung: Remaja Rosdakarya.

Rani, A., dkk (2006). Analisis Wacana Sebuah Kajian Bahasa dalam Pemakaian. Malang: Bayu Media Publishing.

Sadiman, A. dkk. (2011). Media Pendidikan (Pengertian Pengembangan dan Pemanfaatannya). Jakarta: Raja Grafindo Persada.

Semi, A. (2007). Menulis Efektif. Padang: Angkasa Raya.

Slamet, S. (2008). Dasar-Dasar Pembelajaran Bahasa dan Sastra Indonesia di Sekolah Dasar. Surakarta: UNS Press.

Sriani, N. (2015). Penerapan Model Pembelajaran Experiential Learning untuk Meningkatkan Kemampuan Menulis Paragraf Deskripsi Pada Siswa Kelas VII B SMP Negeri 2 Tampangsiring. e-Journal Universitas Pendidikan Ganesha Jurusan Pendidikan Bahasa dan Sastra Indonesia. Universitas Pendidikan Ganesha.

Subagyo, P. (2004). Metode Penelitian: Dalam Teori dan Praktek. Jakarta: Rineka Cipta

Sudaryanto. (2008). Metode dan Aneka Teknik Analisis Bahasa ( Pengantar Penelitian Wahana Kebudayaan secara Linguistik). Yogyakarta: Duta Wacana University Press.

Sudjana, N. (2005). Penilaian Hasil Proses Belajar Mengajar. Bandung: Remaja Rosdakarya.

Sumarsono, S. (2004). Teknik Penulisan Laporan. Jakarta: Graha IImu

Suparno, dan M. Yunus. (2007). Ketrampilan Dasar Menulis. Jakarta: Universitas Terbuka.

Sutardi, K. (2012). Penulisan Sastra Kreatif. Yogaykarta: Graha IImu.

Sutopo, B.H (2002). Metodologi Penelitian Kualitatif. Surakarta: Sebelas Maret University Press.

Suyatno. (2008). Teknik Pembelajaran Bahasa dan Sastra. Surabaya: SIC

Tarigan, H. (2008). Menulis Sebagai Suatu Keterampilan Berbahasa. Bandung :Angkasa 